\title{
Rupture of heart with all layers after a massive blunt thoracic trauma without any lesion on the bones: a case report
}

\author{
Ağır derecede künt gögüs travması sonrası herhangi bir kemik lezyonu olmaksızın \\ kalbin tam kat yırtılmasi: Olgu sunumu
}

İsmail BİRİNCİOĞLU, ${ }^{1}$ Nurşen TURAN, ${ }^{1}$ Muhammet CAN $^{2}$

\begin{abstract}
Our case is a male student which was dead because of traffic accident as passenger in October, 01, 2007. His heart was found to be lacerated and ruptured horizontally from atrioventricular region through all layer of the wall at autopsy. There were not any changes of skeletal system. Our case is considered as a rare and interesting case because there was no lesion on the bones, though the case was exposed to so massive trauma that cause rupture of heart from all layers.
\end{abstract}

Key Words: Blunt thoracic trauma; heart laceration.
Trafik kazası sonucu olay yerinde hayatını kaybeden yolcu, 18 yaşında, erkek, üniversite öğrencisidir. 01.10.2007 tarihinde yapılan otopsisinde kalbin atrio-ventriküler bölgeden yatay olarak tam kat yırtılmış ve kopmuş olduğu saptand, iskelet sisteminde herhangi bir lezyon yoktu. Bu olgu kalpte tam kat yırtılmaya neden olabilecek derecede ağır bir travmaya maruz kalmasına rağmen hiçbir kemik lezyonu olmaması açısından nadir olgu olarak değerlendirildi.

Anahtar Sözcükler: Künt göğüs travması; kalp laserasyonu.
Thorax trauma is a leading cause of traumatic deaths, accounting for $20-25 \%$ of all traumatic deaths in the first 30 years of life..$^{[1,2]}$ Cardiac, lung and big vessel injury may occur in thorax traumas. Lung and cardiac injuries aggravate perfusion and oxygenation of the body and lead to increased morbidity and mortality. ${ }^{[1]}$ Males are more frequently subjected to thorax traumas than females. ${ }^{[1-3]}$

Fatal cardiac lacerations due to blunt thorax trauma are generally diagnosed at autopsy. ${ }^{[4,5]}$

\section{CASE REPORT}

Report of Death Scene and External Physical Examination: The case was 18 years of age and a university student. He was sitting in the passenger side of the vehicle beside the driver who caused the accident. The victim's body was found 10 meters away from the vehicle, which was thrown out on 10 January 2007. The body was sent to the state hospital for external physical examination. Some parts of his body were covered with black motor oil. Except for a few small ecchymoses and lacerations, no lesion or fracture was defined (Fig. 1a, b). No rupture in his t-shirt, athlete or blue jeans was detected.
Autopsy: The autopsy was performed on 10 January 2007.

External Examination: The case was 25 years old, with a height of $182 \mathrm{~cm}$ and weight of $80 \mathrm{~kg}$ on examination. Rigor mortis had not formed but onset of livor mortis was observed on the patient's back. One abrasion on the abdomen, 8 abrasions measuring $1 \mathrm{~cm}$ on his back, one small abrasion on his right cheek, and motor oil contamination on the face, thorax and arms were reported.

Internal Examination: No macroscopic pathology was seen on his head. Both right and left thoracic cavities were filled with blood. The heart was ruptured from the atrioventricular region horizontally. The ventricular region of the heart was found separated in the thoracic cavity (Fig. 2). The abdominal cavity was also filled with blood. The liver and spleen had multiple small lacerations. No skeletal pathology was determined.

Laboratory Examinations: Blood taken via vessel at autopsy was investigated for alcohol and hypnotic and narcotic drugs. No toxic substance was detected from the blood sample.

${ }^{1}$ Department of Forensic Medicine, Karadeniz Technical University Faculty of Medicine, Trabzon; ${ }^{2}$ Department of Forensic Medicine, Balıkesir University Faculty of Medicine, Balıkesir, Turkey.

${ }^{1}$ Karadeniz Teknik Üniversitesi Tıp Fakültesi, Adli Tıp Anabilim Dalı, Trabzon; ${ }^{2}$ Balıkesir Üniversitesi Tıp Fakültesi Adli Tıp Anabilim Dalı, Balıkesir. 


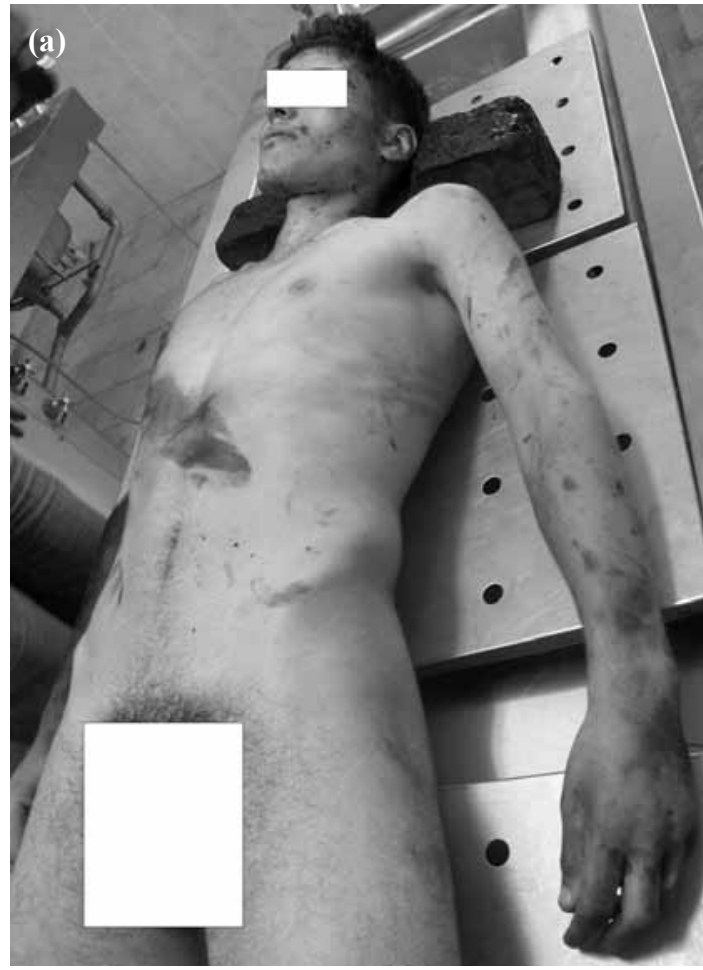

Result of Report: The cause of death was determined to be due to organ laceration and internal hemorrhage due to general body trauma.

\section{DISCUSSION}

In recent years, thoracic trauma cases have increased in conjunction with the increase in the incidences of violence and traffic and occupational accidents. ${ }^{[6]}$ It has been noted that rib and sternum fractures occurring during cardiopulmonary resuscitation may cause cardiac and lung lacerations, and rarely, cardiac rupture and liver laceration. ${ }^{[7]}$ After blunt thoracic trauma, the trachea and bronchus are rarely injured. Penetrative injuries result in organ laceration in many cases. ${ }^{[8]}$

The incidence of cardiac laceration in patients with blunt thoracic trauma has been reported in various studies as $2 \%,{ }^{[9]}$ more than $7 \%,{ }^{[10,11]}$ and more than $15 \%{ }^{[12,13]}$ Cardiac rupture because of one blunt thoracic trauma is very rare. Thoracic traumas causing cardiac laceration have more than one bone fracture (e.g. costae and sternum fractures).$^{[5,10]}$ This type of injury has a wide range of clinical expression, from no clinical finding to serious life-threatening findings like arrhythmia, conduction anomalies, congestive heart failure, cardiogenic shock, hemo-pericardium, pericardial tamponade, valvular rupture, intraventricular thrombus, thromboemboli, air emboli, coronary artery occlusion, ventricular aneurysm, and constructive pericarditis. ${ }^{[12,13]}$ Blunt thoracic traumas causing cardiac rupture have a high mortality rate. It has been shown in some studies that the mortality rate in these cases may be as high as $85 \%{ }^{[14]}$ Cardiac rupture incidence resulting from blunt thoracic trauma is lower in children $(0-43 \%)$ than in adults $(16-76 \%) .{ }^{[15]}$ Cardiac contusion due to blunt thorax trauma is more frequent in children compared to adults. Because the right ventricle wall is thinner than the left, right ventricle injury is more frequent. ${ }^{[10]}$ Aorta rupture incidence is $13-16 \%$ in traffic accidents, and mortality rate in these cases is $70-85 \%{ }^{[16]}$

Cardiac injury frequently occurs in traffic, sportive and occupational accidents and due to intentional trauma. Recently, blunt cardiac injuries have mostly resulted from traffic accidents..$^{[3,10-12,17]}$ Cardiac injuries have been found to occur more frequently with penetrative injury than with blunt injury. ${ }^{[12]}$

A few cases of simultaneous rupture of mitral and tricuspid valves caused by blunt chest trauma have been reported. Papillary muscle rupture is the most common cause of traumatic mitral regurgitation, fol-

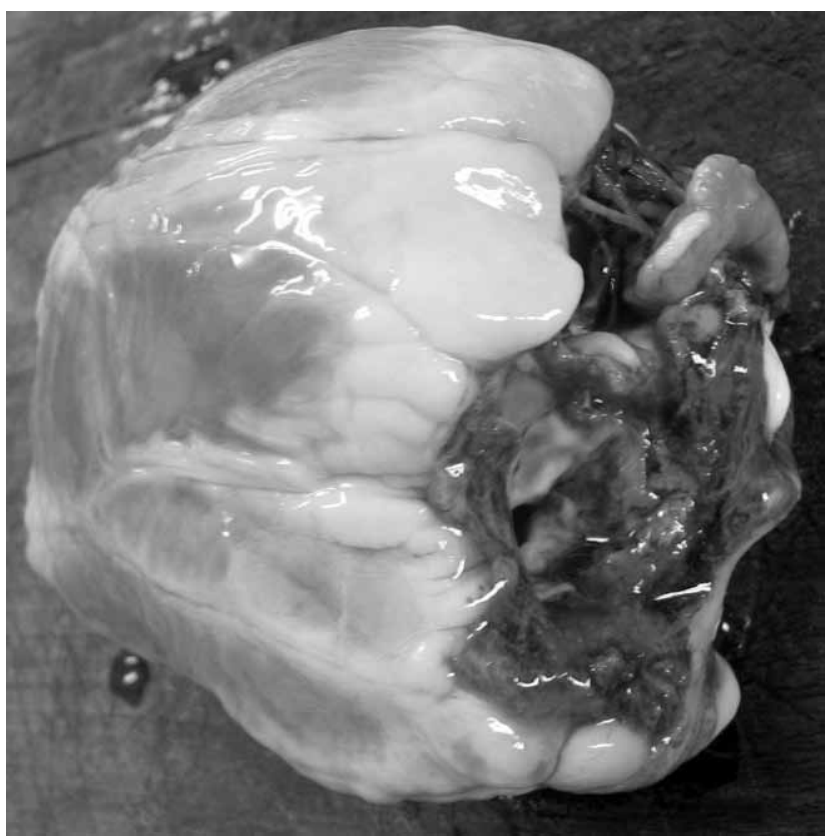

Fig. 2. Cardiac rupture from all layers of the wall. 
lowed by rupture of the chordae tendineae and leaflet tears. In traumatic injury of the tricuspid valve, chordal rupture occurs most frequently, followed by anterior papillary muscle rupture and leaflet tears. Papillary muscle rupture has been purported to occur due to ventricular compression between the sternum and the spine during the period of isovolumic contraction when the cardiac valves are closed. ${ }^{[18]}$

Depending on the mechanism and severity of the trauma, the cardiac injury ranges from a mild contusion to rupture of the cardiac wall. Though rupture of the heart is rare, it is the commonest form of deadly cardiac injury from blunt trauma. Interestingly, the cardiac ruptures are usually discovered at autopsy. The mechanisms of cardiac injury in blunt trauma may be summarized as 1) direct blow to the anterior chest (most common cause of ventricular rupture); 2) indirect injury that causes a sudden increase in preload, resulting in atrial rupture; 3 ) compression of the heart between the sternum and vertebral bodies; 4) acceleration/deceleration of the heart and great vessels; 5) blast injury, and 6) penetrating injury of a cardiac chamber by a fractured rib or the sternum. The heart may be ruptured by compression or from a blow or a fall, usually on its right side and towards its base. ${ }^{[5]}$

In conclusion, contusions or lacerations of the heart may also be produced by blows from a blunt weapon or by compression of the chest, even without fracturing any bone of the thorax and without visible marks of external injury. Therefore, there is always a possibility of fatal cardiac injuries going unnoticed and leading to a fatal outcome.

\section{REFERENCES}

1. Altunkaya A, Aktunc E, Kutluk AC, Buyukates M, Demircan N, Demir AS, et al. Evaluation of 282 cases with thoracic trauma. Türk Gögüs Kalp Damar Cer Derg 2007;15:127-32.

2. Vougiouklakis T, Peschos D, Doulis A, Batistatou A, Mitselou A, Agnantis NJ. Sudden death from contusion of the right atrium after blunt chest trauma: case report. Int J Care Injured 2005;36:213-7.
3. Harel Y, Szeinberg A, Scott WA, Frand M, Vered Z, Smolinski A, et al. Ruptured interventricular septum after blunt chest trauma: ultrasonographic diagnosis. Pediatr Cardiol 1995; 16:127-30.

4. Savolainen HO, Järvinen AA, Vihtonen KM. Left atrial rupture following blunt thoracic injury. Case report. Scand J Thorac Cardiovasc Surg 1991;25:231-4.

5. Meera TH, Nabachandra H. A postmortem study of blunt cardiac injuries. JIAFM 2005;27:82-4.

6. Cobanoglu U. Thoracic trauma: analysis of 110 cases. Toraks Dergisi 2006;7:162-9.

7. Boz B, Erdur B, Acar K, Ergin A, Turkcuer I, Ergin N. Incidence of thoracic cage injury due to cardiopulmonary resuscitation: forensic autopsy results. Ulusal Travma Acil Cerrahi Derg 2008;14:216-20.

8. Helmy N, Platz A, Stocker R, Trentz O. Bronchus rupture in multiply injured patients with blunt chest trauma. Eur J Trauma 2002;1:31-4.

9. De Amicis V, Rossi M, Monaco M, Di Lello F. Right luxation of the heart after pericardial rupture caused by blunt trauma. Tex Heart Inst J 2003;30:140-2.

10. Darok M, Beham-Schmid C, Gatternig R, Roll P. Sudden death from myocardial contusion following an isolated blunt force trauma to the chest. Int J Legal Med 2001;115:85-9.

11. Gölbaşi I, Türkay C, Sahin N, Erdoğan A, Gülmez H, Erbasan O, et al. Heart wounds. Ulus Travma Derg 2001;7:167-71.

12 Cobanoglu U. Investigation of cardiac changes of 70 cases with thoracic trauma. Toraks Dergisi 2007;8:59-68.

13. Markovchick V, Wolfe R. Cardiovascular trauma. In: Morris PJ, Wood WC, editors. Oxford textbook of surgery. 2nd ed. London: Oxford University Pres.; 2001. p. 527-45.

14. Colline EMB, Rodriguez A, Turney SZ, Dunham CM, Cowley RA. Blunt traumatic cardiac rupture: a 5-year experience. Ann Surg 1990;701-4.

15. Baum VC. Cardiac trauma in children. Paediatr Anaesth 2002;12:110-7.

16. von Oppell UO, Thierfelder CF, Beningfield SJ, Brink JG, Odell JA. Traumatic rupture of the descending thoracic aorta. S Afr Med J 1991;79:595-8.

17. Bruschi G, Agati S, Iorio F, Vitali E. Papillary muscle rupture and pericardial injuries after blunt chest trauma. Eur J Cardiothorac Surg 2001;20:200-2.

18. Choi JS, Kim EJ. Simultaneous rupture of the mitral and tricuspid valves with left ventricular rupture caused by blunt trauma. Ann Thorac Surg 2008;86:1371-3. 